\title{
Discussion on the Quiet Beauty of Ancient Literati Landscape Painting
}

\author{
Xiaosha Wang ${ }^{\text {a }}$ \\ Academy of fine arts, China West Normal University, Nanchong 637002, Sichuan, China \\ a601953917@qq.com
}

Keywords: literati and officialdom; landscape painting; prospect; quiet beauty.

\begin{abstract}
There are many kinds of beauty in Chinese traditional landscape painting. The lonely and quiet beauty is a feature in the ancient literati landscape painting. "Look for the heart tranquility and achieve lasting success by leading a quiet life," the core of the quiet beauty formed in these kinds of art works are not these subjects in itself but are conception of the main body of the artist and vitality and soul in the creative process, and they are the soul of the artists reflected in the works.
\end{abstract}

\section{Introduction}

The landscape painting as one of the traditional China's painting subjects in this category of paintings, which has more than 1,500 years of history, and occupies a decisive position in the national painting heritage. The landscape painting is different from the West: Western paintings pursue similarity in form or appearance and based on sculpture, the houses and palaces, trees and flowers of the painting are as vivid as life. The China's painter more admires Laozhuang, forgets the secular world, and observes the rationality of all things in silence; imitate laboriousness is expressed in pen and ink, and it is also the rational interest of this thing. Therefore, China's painting gives people the feeling to abandon material and take spirit, abandon shape and take shade, it can convey turbulence in tranquility, see spirit in the blank space, and show the "quiet and ethereal" beauty. The literati painting is rooted in Chinese traditional culture, whose historical influence in China's painting circles cannot be ignored. As early as the middle period of the Northern Song Dynasty, Emperor Huizong of the Song Dynasty Zhao Ji vigorously promoted the court painting, and some literary scholars outside the court emphasized the subjective feelings, pursued the "pen and ink game" and express one's emotion in painting, and this "game" as a kind of recreation for self-expression. They use pens to convey emotions, and express themselves in ink, the performance objects like to make fun, and the natural charm conveyed gives people another form of beauty to enjoy. The art comes from life, Fu Baoshi pointed out in "Talking Arts": "prospect is rooted in the soil of 'traveling,' prospect is brewing from life. Nature is beautiful. The conception is to integrate the factors of beauty and give full play to it, and make it sublimate into a better, more ideal state." The essence of the beauty is the same, but the form of the beauty is very different. We appreciate the ancient literati landscape painting, mainly show the prospect beauty of landscape through the artist's pen and ink charm, and the important symbol of the literati landscape painting lies in the quiet beauty expressed in the painting. The quiet beauty of landscape painting requires the painter's painstaking efforts to create, but this is not simply the painter's unilateral feeling, it needs to interact with the viewer and resonate. The literati landscape painter likes to "express feeling with thing" and express feeling directly in every hill and every stream, every tree and bush; the viewer can not only appreciate the scenery and prospect in the picture, but also extend the infinite prospect through the picture, in this way, the viewer can cleanse mind, get away from individual and gain spiritual sublimation.

\section{The History of Landscape Painting}

We look back the development history of China's landscape paintings, mountains and rivers emerged as backgrounds in figure paintings long before the mid-Tang Dynasty, until the mid-Tang Dynasty, the continuous changes in social life and the gradual dilution of religious consciousness, landscape painting as an independent category and gained their own unique aesthetics. There was a 
great variation in the social system from the mid-Tang Dynasty to the Northern Song Dynasty, the literati and officialdom's psychological conditions and aesthetic tastes also changed. In Li Zehou's "The History of Beauty," he said: "the literati and officialdom often go from the wild to the court, from agriculture to official business, from the local to the capital, and from the countryside to the cities. The mountain and river, village have become a psychologically necessary supplement and replacement of their riches and pavilions, an emotional memory and pursuit.” It shows that they can't break out of hunting and racing, also like to seek the freedom and easiness of wild stock or floating clouds in the mountains and waters of nature. It also be said that they are in an idle, rest, and passive relationship with nature, they can only be the possessor and appreciator of rural life. The characteristics of this social class are also clearly reflected in China's landscape painting, the kind of entertaining kindness and idyllic serenity make people and nature becomes its basic tones, this quiet and peaceful picture is in line with the aesthetics of the literati and officialdom, and it is the prerequisite for the quiet beauty.

In the Yuan Dynasty, under the rule of its ruthless and backward system, China's social economy and social productivity have been greatly damaged. The rulers broke the Han nationality's domination in the world; the Mongolians are excellent people and discriminate the Han nationality, this makes ordinary Han scholars at the bottom of the society suffer great humiliation and oppression, under this kind of social environment, the aesthetic taste of the literati and officialdom also changed. Some people are forced or willing to give up officialdom is the natural outlet for good scholars this traditional way, they place their time, energy, and emotions on literature and art, landscape painting has also become one of the areas for this sustenance. The national stigma which the country is defeated and the home lost has prompted them to live in solitude and do not concern the manners and morals of the time, the creation of landscapes at this time has become a way to escape the world and entertain themselves. We often say that art comes from life, and Fu Baoshi also pointed out in the "Talking Arts": "The prospect is rooted in the soil of 'tourism', it is brewed from life. Nature is beautiful. The conception is to integrate the factors of beauty, give full play to make it sublimate into a more beautiful and more ideal state.” Therefore, living in a different era atmosphere and living environment, the literati and officialdom' scenery in eyes will be different. They no longer focus on the similarity in form or appearance, no longer pursue the description of natural scenery, but focus on expressing their own subjective consciousness, the temperament and interest of pen and ink is key point of the pursuit, mountains and rivers of pen and ink is mingled with their own thoughts and feelings. Majestic and magnificent landscape style is no longer pursued by the literati and officialdom; they like to describe common scenes with concise pen and ink, thus expressing the quiet beauty prospect of leisure, desolate, peace and calm. As Yang Weizhen said, this is: " valley in silence, fit the heart of lonely people"; "Their works, despite the fact that there are based on real mountains and rivers, but regardless of writing the spring scene, autumn scene, or summer scene, winter scene, writing mountains or shallow slopes always gives people a desolate, mild and cold feeling, and pursue the state of 'world's life.'

In addition, Zen prevailed after the Mid-Tang Dynasty, the philosophical thinking of Zen was similar to the China's traditional Laozhuang, and the literati and officialdom highly praised it. They can use talking about "metaphysics" method to evade the reality and stay away from the darkness of society, in order to obtain comfort and serenity for the soul and indulge and paralyze them. The inaction and detachment thoughts of Laozhuang cater to the literati and officialdom's unearthly thoughts, and more conform to literati and officialdom's need to explore sentiment. Zen, which has a strong influence on literati' paintings, and Laozhuang philosophy will naturally produce a carefree and quiet style of literati painting, this kind of prospect almost exists in all literati paintings to different degrees. In the Qing Dynasty, Fang Xu's wrote in "Discussion on Mountain Paintings", "all rich go away. Mountains and waters, fish and bird are detained. It is suitable for drawing a picture and do not have world's life. "Of course, this state is calm and peaceful. He also said: "The painting cannot be quiet; non-painters are quiet, and the paintings without quiet state. The ancients have no complicated and simple in the paintings, they are still, the imaginative and imaginative person of the 
thought, the painting also, the static painting, does not think of the painter" It is obvious to see his appreciation extent for the quiet prospect.

\section{Conclusion}

In short, the quiet in the ancient literati landscape paintings should actually be "Look for the heart tranquility and achieve lasting success by leading a quiet life”, which is the quiet beauty; it is the standard of the miraculous beauty in the painting, thus becoming a cognitive criterion for beauty. It can fully reflect the ancient literati's quiet heart to quiet painting. The mild and peace mood facilitates the quiet beauty of the picture, as Hegel said, "the content core formed in these kinds art works are not these subjects itself, but are the vitality and soul devoted by the artist's subjective conception and creative processing, and it is the soul of the artists reflected in the works!"

\section{References}

[1]. Li Zehou. The Course of Beauty[M]. Guilin: Guangxi Normal University Press, 2001.

[2]. Wang Bomin. Chinese Painting History[M]. Shanghai. Shanghai People's Fine Arts Publishing House, 1982.

[3]. Lin Mu. Discussion on Literati Painting[M]. Shanghai, Shanghai People's Fine Arts Publishing House, 1987.

[4]. Fang Xun. Shan Jing Ju Hua Lun[M]. Shanghai. Shanghai People's Fine Arts Publishing House, 1959.

[5]. Hegel. Aesthetics[M]. Beijing. The Commercial Press, 1982. 